\title{
PERBANDINGAN ANALISIS PREDIKSI KEBANGKRUTAN MENGGUNAKAN MODEL ALTMAN PERTAMA, ALTMAN REVISI, DAN ALTMAN MODIFIKASI DENGAN UKURAN DAN UMUR PERUSAHAAN SEBAGAI VARIABEL PENJELAS (STUDI PADA PERUSAHAAN MANUFAKTUR YANG TERDAFTAR DI BURSA EFEK INDONESIA)
}

\author{
Ayu Suci Ramadhani \\ Governance Research Program (GRP) \\ Fakultas Ekonomi, Universitas Andalas \\ e-mail:a_aykeygirl@yahoo.com \\ Niki Lukviarman \\ Governance Research Program (GRP) \\ Fakultas Ekonomi, Universitas Andalas \\ e-mail:Lukviarman@yahoo.com
}

\begin{abstract}
This study observes the bankruptcy prediction models introduced by Altman; the First Altman model, the Revised Altman model, and the Modified Altman model to predict bankruptcy for manufacturing companies listed in the Indonesian Stock Exchange. The research was conducted for forty-two manufacturing companies that matched criteria in the selection of the sample over the years 2004-2007 based on published data for the same period. To accommodate various Almant models, the data was then calculated based on financial ratio and the data have been processed further to find the bancruptcy index as suggested by the models. The results of the three models are then compared with the use of company's age and size as descriptive information to predict the company's bankruptcy potential. The result of comparative data in bankruptcy prediction is that; the first Altman provides the highest percentage in predicting the bankruptcy. The research also found that the company categorized under small groups and under the age of 30 were likely to go bankcrupt in compare to the other groups.
\end{abstract}

Keywords:financial distress, bankruptcy Index, bankruptcy prediction model, size of the company, age of the company.

\section{PENDAHULUAN}

Krisis ekonomi yang melanda Indonesia sejak tahun 1998 telah mengakibatkan kesulitan keuangan yang buruk. Hal ini ditandainya dengan banyaknya perusahaan yang ditutup, perbankan yang dilikuidasi dan meningkatnya jumlah tenaga kerja yang menganggur. Pada saat krisis ini pula kondisi industri Indonesia mengalami kesulitan keuangan yang buruk. Menurut catatan BPS, yang mengalami pertumbuhan positif hanyalah sektor pertanian, sektor gas, listrik dan air bersih, dan pengangkutan dan komunikasi. Sementara sektor manufaktur mengalami kesulitan keuangan yang sangat buruk (data BPS mencatat hampir 13\% dari sektor ini mengalami kepailitan).

Industri manufaktur Indonesia semakin memburuk ditambah dengan kondisi krisis ekonomi global yang terjadi mulai 
tahun 2008. Daniri (2008) menyatakan bahwa krisis ini merupakan Krisis ekonomi global yang terjadi paling buruk setelah sekitar 80 tahun terakhir juga di alami krisis yang sama secara global. Krisis ini terjadi karena krisis keuangan di Amerika Serikat, krisis keuangan di Amerika Serikat ini dipicu oleh krisis subprime mortgage pada medio 2006 yang memberikan dampak yang sangat besar terhadap perekonomian dunia termasuk Indonesia. Hal inilah yang menyebabkan banyak perusahaan di sektor manufaktur mengalami kesulitan keuangan (financial distress) dan diprediksikan akan bangkrut.

Financial distress merupakan tahapan penurunan kondisi keuangan suatu perusahaan sebelum terjadinya kebangkrutan ataupun likuidasi. Kebangkrutan juga sering disebut likuidasi perusahaan atau penutupan perusahaan atau insolvensi. Kebangkrutan sebagai kegagalan diartikan sebagai kegagalan keuangan (financial failure) dan kegagalan ekonomi (economic failure).

Untuk mengatasi dan meminimalisir terjadinya kebangkrutan, perusahaan dapat mengawasi kondisi keuangan dengan menggunakan teknik-teknik analisis laporan keuangan. Analisis laporan keuangan merupakan alat yang penting untuk memperoleh informasi yang berkaitan dengan posisi keuangan perusahaan serta hasil yang telah dicapai sehubungan dengan pemilihan strategi perusahaan yang telah diterapkan. Dengan melakukan analisis laporan keuangan perusahaan, maka dapat diketahui kondisi dan perkembangan financial perusahaan. Selain itu, juga dapat diketahui kelemahan serta hasil yang dianggap cukup baik dan potensi kebangkrutan perusahaan tersebut.

Altman (2002) mengembangkan metode kebangkrutan dengan tingkat keakuratan yang dapat dipercaya dalam memprediksi kebangkrutan. Model Altman Z-score sebagai salah satu pengukuran kinerja kebangkrutan dan resiko obligasi tidak stagnan atau tetap, melainkan berkembang dari waktu kewaktu, seiring dari kondisi perusahaan dan kondisi dimana metode tersebut diterapkan.

Perkembangan Model Altman ini dapat dilihat mulai dari yang pertama yaitu model Altman Z-score pertama yang ditujukan untuk memprediksi kebangkrutan dari sebuah perusahaan publik manufaktur. Setelah menemukan model kebangkrutan yang pertama Altman kemudian merevisi model kebangkrutan menjadi sebuah model yang dapat digunakan untuk memprediksi kemungkinan kebangkrutan bagi perusahaan manufaktur privat dan publik, model ini disebut sebagai model Altman revisi atau Z'-score. Selanjutnya Altman memodifikasi modelnya agar dapat diterapkan pada semua perusahaan seperti manufaktur, non manufaktur dan perusahaan penerbit obligasi. Model ini disebut sebagai model Altman modifikasi atau Z'-Score.

Berdasarkan latar belakang diatas penelitian ini bertujuan untuk mengetahui perbandingan antara model-model Altman dalam memprediksi kebangkrutan serta bagaimana ukuran dan umur perusahaan menjelaskan prediksi kebangkrutan pada perusahaan manufaktur yang terdaftar di Bursa Efek Indonesia. Model prediksi yang digunakan adalah model Altman yaitu model Altman pertama, Altman revisi dan Altman modifikasi.

\section{TINJAUAN PUSTAKA}

\section{Kesulitan Keuangan dan Kebangkrutan}

Financial distress (kesulitasn

keuangan) terjadi sebelum kebangkrutan benar-benar dialami oleh perusahaan. Plat dan Plat (2002) mendefinisikan financial distress sebagai tahap penurunan kondisi keuangan yang terjadi sebelum terjadinya kebangkrutan ataupun likuidasi. Sedangkan Foster (1988) mendefinisikan financial distress sebagai: "Financial distress is used 
to mean severe liquidity problems that cannot be resolved without a sizable rescaling of the entity's operations or structure".

Berdasarkan kedua pengertian di atas dapat disimpulkan bahwa kesulitan keuangan adalah suatu situasi dimana arus kas operasi perusahaan tidak memadai untuk melunasi kewajiban-kewajiban lancar (seperti hutang dagang atau beban bunga) dan perusahaan terpaksa melakukan tindakan perbaikan. Dan kesulitan keuangan adalah masalah likuiditas yang sangat parah yang tidak bisa dipecahkan tanpa perubahan ukuran dari operasi atau struktur perusahaan. Informasi Financial distress ini dapat dijadikan sebagai peringatan dini atas kebangkrutan sehingga menajemen dapat melakukan tindakan secara cepat untuk mencegah masalah sebelum terjadinya kebangkrutan.

Kebangkrutan suatu perusahaan ditandai dengan financial distress, yaitu keadaan dimana perusahaan lemah dalam menghasilkan laba atau perusahaan cenderung mengalami defisit. Dengan kata lain, kebangkrutan dapat diartikan sebagai kegagalan perusahaan dalam menjalankan operasi perusahaan untuk memperoleh laba. Kebangkrutan juga sering disebut likuidasi perusahaan atau penutupan perusahaan atau insolvensi. Kebangkrutan sebagai kegagalan diartikan sebagai kegagalan keuangan atau financial failure dan kegagalan ekonomi atau economic failure (Adnan dan Kurniasih, 2000; 137).

Kegagalan dalam arti ekonomi merupakan keadaan dimana perusahaan kehilangan uang atau pendapatan perusahaan tidak bisa menutupi biayanya sendiri. Ini berarti bahwa nilai sekarang dari arus kas sebenarnya lebih kecil dari kewajiban atau laba lebih kecil dari modal kerja. Kegagalan terjadi bila arus kas yang sebenarnya dari perusahaan tersebut jauh di bawah arus kas yang diharapkan. Bahkan, kegagalan juga bisa berarti bahwa tingkat pendapatan dari biaya historis atau investasinya lebih kecil daripada biaya modal perusahaan.

Kegagalan keuangan bisa diartikan sebagai insolvensi yang membedakan antara arus kas dan dasar saham. Insolvensi atas dasar arus kas ada dua bentuk yaitu insolvensi teknik dan insolvensi dalam pengertian kebangkrutan. Insolvensi teknik merupakaan keadaan dimana perusahaan dianggap tidak dapat memenuhi kewajibannya pada saat jatuh tempo. Walaupun total aktiva melebihi total utang atau terjadi bila suatu perusahaan gagal memenuhi salah satu atau lebih kondisi dalam ketentuan hutangnya seperti rasio aktiva lancar terhadap kewajiban lancar yang telah ditetapkan atau total kekayaan bersih terhadap total aktiva yang disyaratkan. Insolvensi teknik juga terjadi bila arus kas tidak cukup untuk memenuhi pembayaran pokok pada tanggal tertentu. Insolvensi dalam pengertian kebangkrutan didefenisikan dalam ukuran sebagai kekayaan bersih negatif dalam neraca konvensional atau nilai sekarang dari arus kas yang diharapkan lebih kecil dari kewajiban.

Kebangkrutan dapat disimpulkan sebagai suatu keadaan atau situasi dalam hal ini perusahaan gagal atau tidak mampu lagi memenuhi kewajiban-kewajiban kepada debitur karena perusahaan mengalami kekurangan dan ketidakcukupan dana untuk menjalankan atau melanjutkan usahanya sehingga tujuan ekonomi yang ingin dicapai oleh perusahaan tidak dapat dicapai yaitu profit, sebab dengan laba yang diperoleh perusahaan bisa digunakan untuk mengembalikan pinjaman, membiayai operasi perusahan dan kewajiban-kewajiban yang harus dipenuhi bisa ditutup dengan laba atau aktiva yang dimiliki. Salah satu dampak dari kebangkrutan ini adalah terjadinya pengurangan karyawan dalam jumlah besar pada beberapa periode waktu sebagai suatu kebi- 
jakan untuk mengurangi biaya operasi perusahaan dan banyaknya kegiatan operasional yang vakum.

\section{Model Prediksi Kebangkrutan}

Untuk mengatasi dan meminimalisir terjadinya kebangkrutan, perusahaan dapat mengawasi kondisi keuangan dengan menggunakan teknik-teknik analisis laporan keuangan. Analisis laporan keuangan merupakan alat yang penting untuk memperoleh informasi yang berkaitan dengan posisi keuangan perusahaan serta hasil yang telah dicapai sehubungan dengan pemilihan strategi perusahaan yang telah diterapkan. Dengan melakukan analisis laporan keuangan perusahaan, maka dapat diketahui kondisi dan perkembangan financial perusahaan. Selain itu, juga dapat diketahui kelemahan serta hasil yang dianggap cukup baik dan potensi kebangkrutan perusahaan tersebut.

\section{Model Springate}

Model ini dikembangkan oleh Springate (1978) dengan menggunakan analisis multidiskriminan, dengan menggunakan 40 perusahaan sebagai sampelnya. Model ini dapat digunakan untuk memprediksi kebangkrutan dengan tingkat keakuratan 92,5\%. Model yang berhasil dikembangkan oleh Springate adalah:

$\mathrm{Z}=1,03 \mathrm{~A}+3,07 \mathrm{~B}+0,66 \mathrm{C}+0,4 \mathrm{D}$

Notasi:

$\mathrm{A}=$ working capital/total asset

$\mathrm{B}=$ net profit before interest and taxes/total asset

$\mathrm{C}=$ net profit before taxes/current liabilities

$\mathrm{D}=$ sales $/$ total asset

Jika $\mathrm{Z}<0,862$ maka perusahaan diklasifikasikan "failed"

\section{Model Zmijewski}

Model Zmijewski (1984) menggunakan analisis rasio yang mengukur kinerja, leverage, dan likuiditas suatu perusahaan untuk model prediksinya. Zmijewski menggunakan probit analisis yang diterapkan pada 40 perusahaan yang telah bangkrut dan 800 perusahaan yang masih bertahan saat itu. Model yang berhasil dikembangkan adalah sebagai berikut:

$X=-4.3-4.5 X_{1}+5.7 X_{2}-0.004 X_{3}$

Notasi:

$\mathrm{X}_{1}=\mathrm{ROA}$ (return on asset)

$\mathrm{X}_{2}=$ Leverage (debt ratio)

$\mathrm{X}_{3}=$ Likuiditas (current ratio)

Fanny dan Saputra (2005) melakukan penelitian mengenai pengaruh model prediksi kebangkrutan terhadap opini audit going concern. Model prediksi kebangkrutan yang digunakan adalah model Altman, model Zmijeweski, dan model Springate. Dari hasil penelitian tersebut, mereka menemukan bahwa model prediksi Altman merupakan model prediksi terbaik diantara ketiga model yang digunakan tersebut dalam mempengaruhi ketepatan pemberian opini audit, selanjutnya diikuti oleh model Springate. Sedangkan penggunaan model Zmijewski memberikan performance terburuk dalam memprediksi kebangkrutan.

Selanjutnya penelitian Hadi dan Anggraeni (2008) berupaya untuk mengetahui model yang terbaik dari ketiga model, yakni model zmijewski, model altman, dan model springate dalam memprediksi perusahaan yang akan delisting. Berdasarkan analisis data dalam penelitian ini dapat disimpulkan bahwa model prediksi Altman merupakan prediktor terbaik di antara ketiga prediktor yang dianalisis.

Model Altman merupakan salah satu metode dengan tingkat keakuratan yang dapat dipercaya dalam memprediksi kebangkrutan, seperti yang telah diungkap pada penelitian-penelitian sebelumnya diatas. Model Altman Z-score sebagai salah satu pengukuran kinerja kebangkrutan dan 
resiko obligasi tidak stagnan atau tetap, melainkan berkembang dari waktu ke waktu, seiring dari kondisi perusahaan dan kondisi dimana metode tersebut diterapkan.

\section{Model Altman}

Altman (1968) adalah orang yang pertama yang menerapkan Multiple Discriminant Analysis. Analisa diskriminan ini merupakan suatu teknik statistik yang mengidentifikasikan beberapa macam rasio keuangan yang dianggap memiliki nilai paling penting dalam mempengaruhi suatu kejadian, lalu mengembangkannya dalam suatu model dengan maksud untuk memudahkan menarik kesimpulan dari suatu kejadian. Analisa diskriminan ini kemudian menghasilkan suatu dari beberapa pengelompokan yang bersifat apriori atau mendasarkan teori dari kenyataan yang sebenarnya.

Dasar pemikiran Altman menggunakan analisa diskriminan bermula dari keterbatasan analisa rasio yaitu metodologinya pada dasarnya bersifat suatu penyimpangan yang artinya setiap rasio diuji secara terpisah sehingga pengaruh kombinasi dari beberapa rasio hanya didasarkan pada pertimbangan para analis keuangan. Oleh karena itu untuk mengatasi kekurangan dari analisa rasio maka perlu kombinasikan berbagai rasio agar menjadi suatu model prediksi yang berarti.

Dengan berdasarkan penelitian analisa diskriminan, Altman melakukan penelitian untuk mengembangkan model baru untuk memprediksikan kebangkrutan perusahaan. Model yang dinamakan z-score dalam bentuk aslinya adalah model linier dengan rasio keuangan yang diberi bobot untuk memaksimalkan kemampuan model tersebut dalam memprediksi. Model ini pada dasarnya hendak mencari nilai "Z" yaitu nilai yang menunjukkan kondisi perusahaan, apakah dalam keadaan sehat atau tidak dan menunjukkan kinerja perusahaan yang sekaligus merefleksikan prospek perusahaan dimasa mendatang.

Dalam menyusun model Z Altman mengambil sampel 33 perusahaan manufaktur yang bangkrut pada periode 1960 sampai 1965 dan 33 perusahaan yang tidak bangkrut dengan lini industri dan ukuran yang sama. Dengan menggunakan data laporan keuangan dari 1 sampai 5 tahun sebelum kebangkrutan, Altman menyusun 22 rasio keuangan yang paling memungkinkan dan mengelompokkannya dalam 5 kategori: likuiditas, profitabilitas, leverage, solvabilitas dan kinerja. Lima macam rasio dari lima variabel yang terseleksi akan di kombinasikan bersama untuk memperoleh prediksi yang paling akurat tentang kebangkrutan.

Penggunaan model Altman sebagai salah satu pengukuran kinerja kebangkrutan tidak bersifat tetap atau stagnan melainkan berkembang dari waktu kewaktu, dimana pengujian dan penemuan model terus diperluas oleh Altman hingga penerapannya tidak hanya pada perusahaan manufaktur publik saja tapi sudah mencakup perusahaan manufaktur non publik, perusahaan non manufaktur, dan perusahaan obligasi korporasi. Berikut perkembangan model Altman:

\section{Model Altman Pertama}

Setelah melakukan penelitian terhadap variabel dan sampel yang dipilih, Altman menghasilkan model kebangkrutan yang pertama. Persamaan kebangkrutan yang ditujukan untuk memprediksi sebuah perusahaan publik manufaktur. Persamaan dari model Altman pertama yaitu

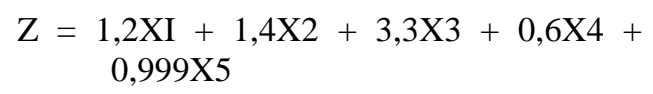

Keterangan:

$\mathrm{Z}$ = bankrupcy index

$\mathrm{X} 1=$ working capital $/$ total asset

$\mathrm{X} 2=$ retained earnings $/$ total asset

$\mathrm{X} 3$ = earning before interest and taxes/total asset 

X4 = market value of equity/book value of total debt
$\mathrm{X} 5$ = sales $/$ total asset .

Nilai Z adalah indeks keseluruhan fungsi multiple discriminant analysis. Menurut Altman, terdapat angka-angka cut off nilai $\mathrm{z}$ yang dapat menjelaskan apakah perusahaan akan mengalami kegagalan atau tidak pada masa mendatang dan ia membaginya ke dalam tiga kategori, yaitu:

a. Jika nilai $\mathrm{Z}<1,8$ maka termasuk perusahaan yang bangkrut.

b. Jika nilai $1,8<\mathrm{Z}<2,99$ maka termasuk grey area (tidak dapat ditentukan apakah perusahaan sehat ataupun mengalami kebangkrutan).

c. Jika nilai $\mathrm{Z}>2,99$ maka termasuk perusahaan yang tidak bangkrut.

\section{Model Altman Revisi}

Model yang dikembangkan oleh Altman ini mengalami suatu revisi. Revisi yang dilakukan oleh Altman merupakan penyesuaian yang dilakukan agar model prediksi kebangkrutan ini tidak hanya untuk perusahaan manufaktur yang go publik melainkan juga dapat diaplikasikan untuk perusahaan-perusahaan di sektor swasta.

Model yang lama mengalami perubahan pada salah satu variabel yang digunakan. Altman mengubah pembilang Market Value Of Equity pada X4 menjadi book value of equity karena perusahaan privat tidak memiliki harga pasar untuk ekuitasnya.

$Z^{\prime}=0,717 \mathrm{X} 1+0,847 \mathrm{X} 2+3,108 \mathrm{X} 3+$

$$
0,42 \mathrm{X} 4+0,988 \times 5
$$

Keterangan:

$\mathrm{Z}^{\prime}=$ bankrupcy index

$\mathrm{X} 1=$ working capital $/$ total asset

$\mathrm{X} 2=$ retained earnings $/$ total asset

$\mathrm{X} 3=$ earning before interest and taxes/total asset

$\mathrm{X} 4=$ book value of equity / book value of total debt
$\mathrm{X} 5=$ sales $/$ total asset.

Klasifikasi perusahaan yang sehat dan bangkrut didasarkan pada nilai Z-score model Altman (1983), yaitu:

a. Jika nilai $Z$ ' 1,23 maka termasuk perusahaan yang bangkrut.

b. Jika nilai $1,23<$ Z' $<2,9$ maka termasuk grey area (tidak dapat ditentukan apakah perusahaan sehat ataupuan mengalami kebangkrutan).

c. Jika nilai Z' > 2,9 maka termasuk perusahaan yang tidak bangkrut.

\section{Altman Modifikasi}

Seiring dengan berjalannnya waktu dan penyesuaian terhadap berbagai jenis perusahaan. Altman kemudian memodifikasi modelnya supaya dapat diterapkan pada semua perusahaan, sepeti manufaktur, non manufaktur, dan perusahaan penerbit obligasi di negara berkembang (emerging market). Dalam Z-score modifikasi ini Altman mengeliminasi variable X5 (sales/total asset.) karena rasio ini sangat bervariatif pada industri dengan ukuran asset yang berbeda-beda. Berikut persamaan Z-Score yang di Modifikasi Altman dkk (1995):

$Z "=6,56 \mathrm{X} 1+3,26 \mathrm{X} 2+6,72 \mathrm{X} 3+1,05 \mathrm{X} 4$

Keterangan:

Z" = bankrupcy index

$\mathrm{X} 1=$ working capital/total asset

$\mathrm{X} 2=$ retained earnings $/$ total asset

$\mathrm{X} 3$ = earning before interest and taxes/total asset

$\mathrm{X} 4$ = book value of equity/book value of total debt

Klasifikasi perusahaan yang sehat dan bangkrut didasarkan pada nilai Z-score model Altman Modifikasi yaitu:

a. Jika nilai Z" < 1,1 maka termasuk perusahaan yang bangkrut.

b. Jika nilai $1,1<Z$ " $<2,6$ maka termasuk grey area (tidak dapat ditentukan apakah 
perusahaan sehat ataupun mengalami kebangkrutan).

c. Jika nilai Z" > 2,6 maka termasuk perusahaan yang tidak bangkrut.

\section{METODE PENELITIAN}

Penelitian ini merupakan penelitian deskriptif komparatif. Tujuan penelitian deskriptif ini adalah untuk menjelaskan tiga model prediksi financial distress dan menganalisis ukuran dan umur perusahaan dalam menjelaskan kebangkrutan perusahaan manufaktur yang terdaftar di Bursa Efek Indonesia. Model yang digunakan dalam penelitian ini adalah model Altman pertama, Altman revisi, dan Altman modifikasi

Selanjutnya, peneliti menggunakan ukuran perusahaan dan umur perusahaan sebagai variabel penjelas (Explanatory Variabel) untuk menjelaskan kebangkrutan pada perusahaan manufaktur.

1. Ukuran perusahaan

Ukuran perusahaan terbagi dalam 2 kategori yaitu perusahaan besar dan perusahaan kecil (pengelompokkan berdasarkan median split). Penentuan ukuran perusahaan ini didasarkan kepada log total asset perusahaan.

2. Umur perusahaan

Umur perusahaan dihitung dari awal mula perusahaan didirikan berdasarkan akte pendirian perusahaan sampai pada tahun perusahaan tersebut diteliti. Umur perusahaan terbagi kedalam 2 kategori yaitu perusahaan berumur diatas 30 tahun dan dibawah 30 tahun (pengelompokkan berdasarkan median split).

Populasi yang digunakan dalam penelitian ini adalah semua perusahaan manufaktur yang terdaftar di Bursa Efek Indonesia (BEI) tahun 2004-2007. Perusahaan yang menjadi sampel dipilih berdasarkan kriteria-kriteria sebagai berikut:
1. Menerbitkan laporan keuangan untuk periode yang berakhir 31 Desember selama periode pengamatan 2004-2007.

2. Mengalami penurunan ROE tiga tahun berturut-turut dalam periode tersebut.

\section{HASIL ANALISIS DAN PEMBAHASAN Hasil Prediksi Kebangkrutan Model Altman Pertama}

Berdasarkan penelitian dengan model Altman pertama terdapat $67,86 \%$ sampel perusahaan manufaktur tahun 2004-2007 yang diprediksi akan mengalami kebangkrutan, ini ditentukan dari Z-score perusahaan yang bernilai kecil dari 1,81. Perusahaan yang diprediksi bangkrut pada tabel 1 memilki Z-score berkisar antara -6,20 sampai dengan 1,806. Dan berdasarkan model Altman pertama diperoleh 24 (dua puluh empat) perusahaan manufaktur yang selalu diprediksi bangkrut dari tahun 2004-2007.

Sedangkan perusahaan manufaktur yang diprediksikan berada pada posisi grey area adalah sekitar 19,05\% dari keseluruhan sampel. Hal ini ditentukan dari Z score yang bernilai diantara 1,81 sampai 2,99. Z-score untuk perusahaan pada kondisi grey area berkisar antara 1,83 sampai dengan 2,86. Sedangkan untuk perusahaan manufaktur yang diprediksi tidak bangkrut adalah $13,10 \%$ dari keseluruhan sampel, yang ditentukan dengan Z-score yang lebih besar dari 2,99. Z-score untuk perusahaan yang diprediksi tidak bangkrut berkisar antara 3,1 sampai dengan 7,04.

\section{Hasil Prediksi Kebangkrutan Model Altman Revisi}

Berdasarkan penelitian dengan model Altman revisi terdapat $50 \%$ sampel perusahaan manufaktur tahun 2004-2007 yang diprediksi akan mengalami kebangkrutan, ini ditentukan dari Z-score perusahaan yang bernilai kecil dari 1,23. Perusahaan yang diprediksi bangkrut pada tabel 2 diatas memilki Z-score berkisar antara -3,8 sampai 
dengan 1,20. Dan berdasarkan model Altman revisi diperoleh 16 (enam belas) perusahaan manufaktur yang selalu diprediksi bangkrut dari tahun 2004-2007.

Perusahaan manufaktur yang diprediksikan berada pada posisi grey area adalah sekitar 39,88\% dari keseluruhan sampel. Hal ini ditentukan dari Z'-score yang bernilai diantara 1,23 sampai 2,9. Z'score untuk perusahaan pada kondisi grey area diatas berkisar antara 1,25 sampai dengan 2,88. Sedangkan perusahaan manufaktur yang diprediksi tidak bangkrut adalah $10,12 \%$ dari keseluruhan sampel, yang ditentukan dengan $Z$ ' score yang lebih besar dari 2,99. Z'-score untuk perusahaan yang diprediksi tidak bankrut berkisar antara 2,9 sampai dengan 5,09.

\section{Hasil Prediksi Kebangkrutan Model Altman Modifikasi}

Berdasarkan penelitian dengan model model Altman modifikasi terdapat 51,19\% sampel perusahaan manufaktur tahun 20042007 yang diprediksi akan mengalami kebangkrutan, ini ditentukan dari Z-score perusahaan yang bernilai kecil dari 1,1. Perusahaan yang diprediksi bangkrut pada tabel 3 diatas memilki Z-score berkisar antara -23,98 sampai dengan 0,96. Dan berdasarkan model Altman revisi terdapat 16 (enam belas) perusahaan manufaktur yang selalu diprediksi bangkrut dari tahun 2004-2007.
Perusahaan manufaktur yang diprediksikan berada pada posisi grey area adalah sekitar $21,43 \%$ dari keseluruhan sampel. Hal ini ditentukan dari Z"-score yang bernilai diantara 1,1 sampai 2,6. Z'score untuk perusahaan pada grey area diatas berkisar antara 1,29 sampai dengan 2,53. Perusahaan manufaktur yang diprediksi tidak bangkrut adalah $27,35 \%$ dari keseluruhan sampel, yang ditentukan dengan Z"score yang lebih besar dari 2,6, dengan Z"-score perusahaan yang diprediksi tidak bangkrut diatas berkisar antara 2,69 sampai dengan 11,30 .

\section{Perbandingan Z-Score Model-Model Prediksi Kebangkrutan Altman}

Setelah dilakukan perhitungan dengan masing-masing model Altman dan telah diperoleh hasil prediksi kebangkrutannya. Selanjutnya dibandingkan antara hasil model Altman dengan tujuan untuk melihat perbedaan dan kemampuan masingmasing model dalam memprediksi kebangkrutan.

Berikut adalah perbandingan hasil prediksi kebangkrutan dari model Altman pertama, revisi dan modifikasi. Tujuannya adalah untuk mengetahui model manakah yang memprediksi kebangkrutan paling tinggi.

Tabel 1:Perbandingan Persentase Kebangkrutan Tiga Model Altman Tahun 2004 - 2007

\begin{tabular}{cccc}
\hline \multirow{2}{*}{ Tahun } & \multicolumn{3}{c}{ Persentase Kebangkrutan } \\
\cline { 2 - 4 } & Altman Pertama & Altman Revisi & Altman Modifikasi \\
\hline 2004 & $66,67 \%$ & $47,62 \%$ & $50 \%$ \\
2005 & $69,05 \%$ & $50 \%$ & $50 \%$ \\
2006 & $64,29 \%$ & $50 \%$ & $52,38 \%$ \\
2007 & $69,05 \%$ & $52,38 \%$ & $52,38 \%$ \\
\hline
\end{tabular}

Sumber: Data diolah 
Dari perbandingan antara model Altman pertama, revisi dan modifikasi dapat dilihat bahwa model Altman pertama yang memprediksi kebangkrutan paling tinggi. Hal ini dapat dilihat dari persentase perusahaan yang bangkrut dari tahun 2004 sampai dengan 2007 yang lebih besar dari prediksi altman revisi dan modifikasi. Untuk model Altman revisi dan modifikasi memprediksi kebangkrutan tidak jauh berbeda dilihat dari persentasenya ditahun 2005 dan 2007 yang bernilai sama yaitu $50 \%$ dan $52,38 \%$. Ditahun 2004 dan 2006 model Altman revisi memprediksi kebangkrutan yang paling rendah dari model prediksi lainnya.

Jadi secara keseluruhan dapat disimpulkan bahwa prediksi kebangkrutan dengan ketiga model Altman yang dibandingkan setiap tahunnya menunjukkan bahwa model Altman pertama memprediksi kebangkrutan yang paling tinggi. Hal ini dinilai dari hasil prediksi Altman pertama yang selalu memprediksi bangkrut lebih banyak setiap tahunnya jika dibandingkan dengan model Altman revisi dan modifikasi.

Ukuran dan Umur Perusahaan dalam Menjelaskan Prediksi Kebangkrutan

Ukuran perusahaan dinilai dari ratarata $\log$ total asset tahun 2004-2007. Berikut adalah perbandingan hasil prediksi kebangkrutan dari model Altman pertama, revisi dan modifikasi dengan ukuran perusahaan, pada table 2 .

Pada table: 3 dapat dilihat bahwa dengan menggunakan ketiga model Altman persentase perusahaan yang diprediksi bangkrut untuk perusahaan kecil memiliki persentase yang paling besar dari pada kebangkrutan untuk kelompok perusahaan besar. Ini menunjukkan bahwa perusahan kecil memiliki kemungkinan yang besar untuk mengalami kebangkrutan dari pada perusahaan besar. Walaupun demikian berdasarkan penelitian ada beberapa perusahaan kecil yang berada pada kondisi grey area dan tidak bangkrut. Salah satunya yaitu PT Sepatu Bata Tbk yang diprediksi tidak bangkrut oleh ketiga model Altman dari tahun 2004-2007.

Jadi secara keseluruhan baik perusahaan besar, maupun kecil perusahaan tersebut memiliki kemungkinan untuk diprediksi bangkut oleh ketiga model Altman hal ini dapat diketahui dari hasil penelitian yang menunjukkan bahwa adanya perusahaan besar, maupun kecil yang diprediksi bangkrut. Walaupun perusahaan kecil memiliki kemungkinan kebangkrutan yang lebih besar dari pada perusahaan besar.

Sedangkan untuk umur perusahaan manufaktur ini dihitung dari awal berdirinya perusahaan berdasarkan akta pendiriannya sampai pada tahun 2007. Perusahaan diklasifikasikan atas perusahaan berumur dibawah 30 tahun dan perusahaan berumur diatas 30 tahun, dimana untuk masingmasing kelompok terdiri dari 21 perusahaan. Berikut adalah perbandingan hasil prediksi kebangkrutan dari model Altman pertama, revisi dan modifikasi dengan umur perusahaan, table 3 .

Tabel 2:Perbandingan Ukuran Perusahaan Dan Persentase Kebangkrutan Model AltmanTahun $2004-2007$

\begin{tabular}{lccc}
\hline \multirow{2}{*}{ Ukuran Perusahaan } & \multicolumn{3}{c}{ Persentase Kebangkrutan } \\
\cline { 2 - 4 } & Altman pertama & Altman revisi & Altman Modifikasi \\
\hline Perusahaan Besar & $66,67 \%$ & $48,81 \%$ & $42,86 \%$ \\
Perusahaan Kecil & $67,86 \%$ & $46,43 \%$ & $60,71 \%$ \\
\hline Sun
\end{tabular}


Jurnal Siasat Bisnis Vol. 13 No. 1, April 2009 Hal: 15-28

Tabel 3: Perbandingan Umu Perusahaan Dan Persentase Kebangkrutan Model AltmanTahun $2004-2007$

\begin{tabular}{lccc}
\hline \multicolumn{1}{c}{$\begin{array}{c}\text { Kelompok Umur } \\
\text { Perusahaan }\end{array}$} & Altman Pertama & Altman Revisi & Altman Modifikasi \\
\cline { 2 - 4 } & $77,38 \%$ & $58,33 \%$ & $59,52 \%$ \\
\hline $\begin{array}{l}\text { Perusahaan umur dibawah } 30 \\
\text { tahun }\end{array}$ & $57,14 \%$ & $41,67 \%$ & $42,86 \%$ \\
$\begin{array}{l}\text { Perusahaan umur diatas } \\
\text { tahun }\end{array}$ & & & \\
\hline
\end{tabular}

Sumber: Data diolah

Berdasarkan penelitian perusahaan manufaktur berumur dibawah 30 tahun diprediksi bangkrut oleh Altman pertama yaitu 77,38\%, Altman revisi 58,33\%, Altman modifikasi, 59,52\% dari keseluruhan sampel perusahaan manufaktur kelompok umur dibawah 30 tahun. Ini menunjukkan bahwa model Altman pertama memprediksi bangkrut paling tinggi untuk perusahaan manufaktur berumur dibawah 30 tahun. Selanjutnya perusahaan manufaktur berumur diatas 30 tahun diprediksi bangkrut oleh Altman pertama yaitu $57,14 \%$, Altman revisi 41,67\%, Altman modifikasi 42,86\% dari keseluruhan sampel perusahaan manufaktur kelompok umur dibawah 30 tahun. Dari kedua kelompok umur tersebut model Altman revisi memprediksi bangkrut paling rendah.

Pada tabel diatas dapat dilihat bahwa dengan menggunakan ketiga model Altman persentase perusahaan yang diprediksi bangkrut untuk perusahaan manufaktur kelompok umur dibawah 30 tahun memiliki persentase kebangkrutan yang paling besar dari pada kelompok perusahaan manufaktur berumur diatas 30 tahun. Ini menunjukkan bahwa perusahaan manufaktur kelompok umur dibawah 30 tahun memiliki kemungkinan yang besar untuk mengalami kebangkrutan.

Walaupun perusahaan pada kelompok umur dibawah 30 tahun memilki kemungkinan bangkrut yang lebih besar pada penelitian, tapi pada perusahaan diatas umur 30 tahun juga terdapat beberapa perusahaan manufaktur yang diprediksi bangkrut. Dapat disimpulkan bahwa baik perusahaan tersebut berumur masih muda ataupun berumur tua perusahaan tersebut dapat diprediksi akan mengalami kebangkrutan. Umur suatu perusahaan tidak selalu menjamin bahwa perusahaan tersebut merupakan perusahaan yang memiliki kondisi keuangan yang sehat. Semakin bertambahnya suatu umur perusahaan belum tentu perusahaan tersebut akan terbebas dari kemungkinan kebangkrutan. Jadi baik perusahaan tersebut berumur muda ataupun tua perusahaan tersebut memiliki kemungkinan untuk diprediksi bangkrut tergantung dari kondisi keuangan perusahaan tersebut.

Penelitian ini hanya menggunakan model Altman dalam memprediksi kebangkrutan, tetapi berdasarkan hasil dari ketiga model Altman untuk perusahaan manufaktur yang dijadikan sampel menghasilkan $\mathrm{Z}$ score dan hasil prediksi yang berbeda. Nilai $\mathrm{Z}$ yang berbeda ini dikarenakan untuk masing-masing persamaan Altman memiliki nilai koefisien, serta nilai pisah batas untuk hasil prediksi kebangkrutan yang berbeda.

Berdasarkan penelitian dengan menggunakan model Altman dari ketiga model tersebut model Altman pertama yang memberikan tingkat prediksi kebangkrutan yang paling tinggi selama periode penelitian. Hal ini didasari karena model Altman pertama ini adalah model prediksi 
kebangkrutan yang dapat digunakan untuk perusahaan manufaktur go public.

Perusahaan manufaktur yang diprediksi bangkrut adalah perusahaan yang memiliki kondisi keuangan yang tidak sehat. Perusahaan yang mengalami kondisi keuangan yang tidak sehat ini karena adanya faktor dari internal dan eksternal perusahaan. Faktor internal tersebut adalah terlalu besarnya kredit yang diberikan kepada debitur atau pelanggan, manajemen yang tidak efisien serta penyalahgunaan wewenang yang dilakukan oleh karyawan dan kadang oleh manajer puncak sangat merugikan, apalagi kecurangan itu berhubungan dengan keuangan perusahaan. Sedangkan faktor ekternal yaitu seperti ekonomi, sosial, kemajuan teknologi, peraturan pemerintah, pelanggan pemasok dan pesaing.

Selanjutnya secara umum dari penelitian dengan menggunakan ukuran sebagai penjelas, dari ketiga model Altman persentase perusahaan yang diprediksi bangkrut untuk perusahaan kecil memiliki persentase yang paling besar dari pada kemungkinan kebangkrutan untuk kelompok perusahaan besar. Ini menunjukkan bahwa perusahaan kecil memiliki kemungkinan yang besar untuk mengalami kebangkrutan dari pada perusahaan besar. Walaupun demikian pada penelitian ini ada beberapa perusahan kecil yang memiliki kondisi keuangan yang sehat dan diprediksi tidak bangkrut, kemungkinan bangkrut untuk perusahaan kecil lebih besar tapi hal tersebut juga tidak menutup kemungkinan untuk perusahaan besar diprediksi bangkrut seperti yang diperoleh pada penelitian ini yaitu perusahan besar ada yang diprediksi bangkrut oleh ketiga model Altman. Jadi perusahaan yang diprediksi mengalami kebangkrutan dapat dialami oleh perusahaan besar maupun kecil. Hal ini terjadi karena adanya faktor-faktor lain yang mempengaruhinya yaitu faktor internal dan eksternal.
Sama halnya dengan ukuran perusahaan, secara umum dari penelitian dengan menggunakan umur sebagai penjelas, perusahaan yang berumur dibawah 30 tahun memiliki kemungkinan bangkrut lebih besar dari pada perusahaan manufaktur kelompok umur diatas 30 tahun, walaupun demikian dari kedua pengelompokan tersebut untuk masing-masingnya ada perusahaan yang diprediksi bangkrut, dan perusahaan tidak bangkrut. Ini menunjukkan bahwa perusahaan yang telah berdiri lama hal ini tidak menjamin bahwa perusahaan tersebut tidak akan mengalami kebangkrutan atau selalu berada pada kondisi keuangan yang sehat. Jadi perusahaan dengan umur berapapun dapat mengalami kondisi keuangan yang kurang sehat atau dapat diprediksi mengalami kebangkrutan dari hasil perhitungan ketiga model Altman. Hal ini terjadi karena adanya faktor-faktor lain yang mempengaruhinya yaitu faktor internal dan eksternal.

Kebangkrutan dapat disimpulkan sebagai suatu keadaan atau situasi dalam hal ini perusahaan gagal atau tidak mampu lagi memenuhi kewajiban-kewajiban kepada debitur karena perusahaan mengalami kekurangan dan ketidakcukupan dana untuk menjalankan atau melanjutkan usahanya sehingga tujuan ekonomi yang ingin dicapai oleh perusahaan tidak dapat dicapai yaitu profit, sebab dengan laba yang diperoleh perusahaan bisa digunakan untuk mengembalikan pinjaman, membiayai operasi perusahaan dan kewajiban-kewajiban yang harus dipenuhi bisa ditutup dengan laba atau aktiva yang dimiliki.

Berdasarkan penjabaran di atas, investor, kreditor, auditor, pemerintah, dan pemilik perusahaan dapat memperoleh gambaran besar kecilnya kemungkinan perusahaan tersebut akan mengalami kebangkrutan atau tidak berdasarkan pertimbangan pada ketiga model pediksi kebangkrutan Altman pertama, revisi dan modifikasi. Prediksi ke- 
bangkrutan perusahaan dapat membantu pembuat keputusan untuk menentukan sikap terhadap perusahaan yang mengalami kesulitan keuangan. Hasil prediksi kebangkrutan tidak hanya berguna untuk pihak internal perusahaan dalam evaluasi kinerjanya, tapi juga dapat digunakan oleh pihak eksternal seperti kreditor, investor, pemerintah, auditor, dimana prediksi kebangkrutan perusahaan dapat membantu pembuat keputusan untuk menentukan sikap terhadap perusahaan yang mengalami kesulitan keuangan.

\section{PENUTUP \\ Kesimpulan}

Model-model prediksi kebangkrutan yang digunakan dalam penelitian ini adalah model Altman yaitu model Altman pertama, revisi dan modifikasi. Dari ketiga model yang digunakan, model Altman pertama memberikan tingkat prediksi kebangkrutan yang paling tinggi dibandingkan dengan model Altman revisi dan Altman modifikasi.

Perusahaan manufaktur yang diprediksi bangkrut dengan menggunakan ketiga model Altman, untuk kelompok perusahaan kecil memiliki persentase prediksi kebangkrutan yang paling tinggi dari pada prediksi kebangkrutan untuk kelompok perusahaan besar. Dimana model Altman pertama memprediksi kebangkrutan paling tinggi untuk kelompok perusahaan kecil ini. Walaupun demikian berdasarkan penelitian perusahaan manufaktur yang diprediksi mengalami kebangkrutan dapat dialami oleh kelompok perusahaan manufaktur kecil, maupun perusahaan manufaktur besar.

Perusahaan yang diprediksi bangkrut dengan menggunakan ketiga model Altman, untuk kelompok perusahaan berumur dibawah 30 tahun memiliki persentase prediksi kebangkrutan yang paling tinggi dari pada kelompok perusahaan manufaktur berumur diatas 30 tahun. Dimana model Altman pertama memprediksi kebangkrutan paling tinggi untuk perusahaan manufaktur kelompok umur dibawah 30 tahun ini. Walaupun demikian perusahaan manufaktur yang diprediksi mengalami kebangkrutan dapat dialami perusahan yang telah lama berdiri maupun perusahaan baru.

\section{Saran}

Diharapkan penelitian-penelitian selanjutnya dapat menggunakan model-model prediksi kebangkrutan lainnya. Untuk dapat dijadikan sebagai pembanding dalam memprediksi kebangkrutan.

Keterbatasan dalam penelitian ini terkait dengan jumlah variabel yang digunakan hanya untuk penilaian kuantitatif saja, sehingga untuk penelitian selanjutnya dapat mempertimbangkan pula aspek kualitatif seperti faktor ekonomi, sosial, teknologi, dan perubahan peraturan pemerintah yang menyebabkan kebangkrutan suatu perusahaan.

\section{DAFTAR PUSTAKA}

Adnan, Muhammad Akhyar dan Kurnayasih, Eha. (2000). Analisis Tingkat Kesehatan Perusahaan Untuk Memprediksi Potensi Kebangkrutan Pada Penekatan Altman (Kasus Pada Sepuluh Perusahaan Di Indonesia), Jurnal Akuntansi Dan Auditing Indonesia, 4 (2), 131-149.

, dan Muhammad Imam Taufiq. (2001), Analisis Ketepatan Prediksi Metode Altman terhadap Terjadinya Likuidasi pada Lembaga Perbankan (Kasus Likuidasi Perbankan di Indonesia). Jurnal Akuntansi dan Auditing Indonesia, 5 (2), 181-201.

Almilia, Lucia Spica. (2006). Prediksi Kondisi FinancialDistress Pada Perusahaango Publik Dengan Menggunkan Analisis Multinomial 
Logit. Jurnal Ekonomi Dan Bisnis, XII (1), Maret 2006.

, dan Kristijadi, Emanuel. (2003). Analisis Rasio Keuangan Untuk Memprediksi Kondisi Financial Distress Perusahaan Manufacture yang Terdaftar Di Bursa Efek Jakarta. Jurnal Akuntansi dan Auditing Indonesia, 7 (2).

, dan Meliza Silvy. (2003). Analisis Faktor-Faktor yang Mempengaruhi Status Perusahaan Pasca IPO dengan Analisis Multinomial Logit. Jurnal Ekonomi dan Bisnis Indonesia (JEBI). 18. (4).

Altman, E. (1968), Financial Ratios, Discriminant Analysis and the Prediction of Corporate Bankruptcy. Journal of Finance 23, September 1968, 589-609.

, (2002). Corporate Financial Distress. New York: John Wiley \& Sons, 1983.

, J. Hartzell, and M. Peck, (1995). Emerging Markets Corporate Bonds: A Scoring System. New York: Salomon Brothers Inc.

Beaver, W. (1967). Financial Ratios as Predictors of Failures. Empirical Research in Accounting, selected studies, 1966, in supplement to the Journal of Accounting Research. January.

Brahmana, Rayendra. (2008). Identifying Financial Distress Condition in Indonesia Manufacture Industry. http://ppiuk.files.wordpress.com/20 07/06/jurnal-raye.pdf. Diunduh pada tanggal 13 Oktober 2008.

Daniri, Achmad. (2008). Bersiap Menghadapi Krisis Ekonomi 2009. http://www.madaniri.com/2008/12/24/Bersiap

Menghadapi Krisis Ekonomi 2009/. Diunduh pada tanggal 15 desember 2008.

Fanny, Margareta dan Saputra, Sylvia. (2005). Opini Audit Going Concern: Kajian Berdasarkan Model Prediksi Kebangkrutan, Pertumbuhan Perusahaan, dan Reputasi Kantor Akuntan Publik (Studi pada Emiten Bursa Efek Jakarta). Makalah Simposium Nasional Akuntansi VIII Solo, 1516 September 2005.

Foster G (1986). Financial Statement Analysis. 2nd edition. USA: Prentice Hall Int. Inc.

Handayani, Wuri. (2008). Analisis Prediksi Financial Distress (Study Kasus Pada PT. Kereta Api (Persero) Sumbar). Skripsi S1. Padang : Universitas Andalas.

Ohlson, James. (1980). Rasio Keuangan dan Kemungkinan Prediksi Kebangkrutan. Terjemahan Firman. http://www.library.usu.ac.id/downl oad/fe/Akuntansi-Firman2.pdf. Diunduh pada tanggal 15 desember 2008.

Platt, H., dan M. B. Platt. (2002). Predicting Financial Distres. Journal of Financial Service Professionals, 56: 12-15.

Sarjono, Hariyadi. (2006). Analisis Laporan Keuangan Sebagai Alat Prediksi Kemungkinan Kebangkrutan Dengan Model Diskriminan Altman Pada Sepuluh Perusahaan Properti di Bursa Efek Jakarta. http://google.com//Analisis_Keban gkrutan_Perusahaan/Analisis_pdf. 
Jurnal Siasat Bisnis Vol. 13 No. 1, April 2009 Hal: 15-28

Diunduh pada tanggal 15 desember 2008.

Yuliardi. (2007). Analisis Perbandingan Metode Memprediksi Kebang- krutan pada Perusahaan Yang Terdaftar di Bursa Efek Jakarta (kasus Tiga Periode Sebelum Kebangkrutan). Skripsi S1. Padang: Universitas Andalas. 